\title{
THE COMPETITIVENESS OF POLISH AGRICULTURE AFTER ACCESSION TO THE EU
}

\author{
Marek Wigier ${ }^{1}$
}

\begin{abstract}
The purpose of doing business in agriculture is to achieve the best possible economic effect with the available factors of production. Production factors, which are determined by their quantity and quality, create a definite production potential. Socio-economic transformations that took place in Poland in the period of EU membership caused a number of structural changes in the resources and distribution of production factors in agriculture. As compared to other sectors of the economy the changes in the agricultural sector seem relatively the most significant ones. The material presented below includes: a brief presentation of the place and the role of agriculture in the Polish economy, analysis of structural changes in the 2002-2012 period, information concerning economic results of the agricultural sector and financial dimension of public policies for agriculture and conclusions from this assessment referring to the issues of competitiveness and efficiency of the Polish sector.
\end{abstract}

Key words: structural changes in agriculture, competitiveness of agriculture, efficiency of agriculture, State aid for agriculture, Common Agricultural Policy.

JEL: $Q 18, Q 10$

\section{Introduction and research objectives}

Poland's membership in the EU has radically changed the economic conditions of functioning in the Polish agriculture and rural areas. The most important sources of these changes, of course, apart from the European Single Market and macro-economic conditionalities, include Common Agricultural Policy (CAP) and structural funds. Today, we already know that CAP has actually caused an increase in support for agriculture, while structural funds have triggered considerable cash flows intended for modernisation of food economy and rural areas development. As compared to other sectors of the economy the changes in the agricultural sector seem relatively the most significant ones. The research presented below aims at showing the character and pace of changes taking place in economic structures in agriculture under the influence of socio-economic transformations and Poland's membership

1 Marek Wigier, Ph.D., Institute of Agricultural and Food Economics - National Research Institute, Świętokrzyska 20, 00-002 Warsaw, Poland, Phone: +48 2250544 38, E-mail: wigier@ierigz.waw.pl

EP 2014 (61) 1 (87-102) 
in the EU, as well as those related to CAP implementation and relate them the issues of competitiveness and efficiency of the agricultural sector.

The paper adopts competitiveness and efficiency of Polish farms as indicators of their economic strength. Evaluating competitiveness we take into account the resources of production factors, efficiency of their use, dynamic and direction of structural changes. Wysokińska (Wysokińska, 2001) links competitiveness to efficient use of resources of production factors, as well as structural changes taking place in the economy resulting in increased efficiency of farming. According to Meredyk (Meredyk, 2001) competitiveness is a feature of economic growth and follows directly from the quantity and quality of labour. M. Porter sees competitiveness through the eye of the ability to create conditions favourable for development of the international competitiveness of companies under individual national industries and branches (Porter, 1995). The definition of competitiveness relies more and more often on two interconnected pillars of efficiency and quality, since it is the quality of products that preconditions the prices and possibilities of sales. Numerous authors, such as G. Hamel, C. K. Prahalad, J. Barney, J. Kay, M. Cassone do not define competitiveness although they analyse it in their works. Thus competitiveness analysis can be conducted ex post - by assessing the result of competition at a defined moment in time, or ex ante - by referring it to a long-term ability to keep or improve the present competitive position.

On the other hand, the economic efficiency is understood as the ratio of achieved effects to the incurred inputs. The economic effect for farms is the income obtained from agricultural activity generated by them, whereas the input is the total labour input expressed in AWU or labour of farm family members in $\mathrm{FWU}^{2}$. Many authors commonly use these indicators as measures of economic efficiency of agricultural enterprises (Józwiak, 2009; Goraj, Mańko 2011). However, agricultural enterprises and farms do not usually compete directly with comparable enterprises on foreign markets. Entities that are directly present on international markets and compete there are agri-food processing enterprises and trade enterprises (Ziętara, 2012). Quality and price of the offered products preconditions their tendering strength. They are most of all dependants on raw materials that are delivered by farms and agricultural enterprises. According to Woś the costs of raw materials constitute two-thirds of costs incurred by the food industry (Woś 2003). Although agricultural producers are not directly present on international markets they have an indirect impact on competitiveness of agri-food products.

The following analysis has been performed through the prism of competitiveness of resources allocation. Since farming is based on the assumption those resources are limited and that the choices are made in a rational manner. Thus the main focus has been drawn to production resources (land, labour and capital) referring to their quantity (sometimes also their quality) and agricultural structures influencing the used production potential expressed by resources.

2 AWU (annual work unit) - equivalent of labour input of 1 full-time employee (2,200 manhour/year). FWU (family work unit) - labour input of farmer and his family members $(2,200$ man-hour/year). 
The analysis has been supplemented with references to the sectoral competitiveness shaped through economic policy instruments (primarily CAP) which directly and indirectly influences the competitive possibilities of agriculture. Statistical data used for analytical purposes in this article were taken from the databases or published materials concerning economic results of farms covered by the FADN ${ }^{3}$ accountancy system, macroeconomic data of the Economic Accounts for Agriculture (EAA), results of CAP implementation provided by the Agency for Restructuring and Modernisation of Agriculture (ARMA) as well as literature studies.

\section{Agriculture in the national economy}

The position and role of agriculture in economic development depend on the economic situation of the country (Nicholls, 1964). The development of agriculture usually follows the overall economic development of the country (Rostow, 1960). The improvement of agricultural productivity increase food self-sufficiency level, contributes to the growth of agricultural incomes, and thus creates the purchasing power of farmers for the purchase of goods and services. The industrialization of the country determines ultimately about of agricultural development, opportunities and pace of its modernization and outflow of the workforce, which is one of the conditions of its technical modernization. Industrialization causes mass structure-forming processes, a symptom of which is the migration of people from rural to urban area. Technical progress and departure of people from agriculture contribute to improving the performance of other sectors of economy employees, and of work expenses reduction. This happens thus far as long as from agriculture departs the persons whose marginal productivity is negative or below in the other sectors of economy. This phenomenon is beneficial for both agriculture and the entire national economy. When agriculture leaves the people with a positive marginal productivity, farm organization and applied technologies is changing. The mechanism of substitution of labour by capital enables the development of production.

In the years preceding Poland's accession to the EU, in 2004 and the following years structural changes took place in agriculture in the field of employment, utilised agricultural land, production organisation, level of input and progress made. Sometimes they were rather dynamic (e.g. changes in the production structure), on other cases they took place over generations (employment in agriculture). Usually they were a continuation of the already existing trends (sometimes with slight changes in their intensity), however, on other cases their directions changed due to new circumstances. After 2004, multiannual trends were continued which were expressed in a slower decrease in the area of agricultural land, sown area or livestock population. They were accompanied by an increased intensity of plant and animal production, crops and unit efficiency of livestock production.

Despite structural changes, sometimes very deep, the Polish agriculture remains an important sector of our Polish economy. This is, primarily, confirmed by the structure of employment and structure of land use. The sector plays an especially important role as it comes to social and economic development of rural areas. Since agriculture uses over

3 Farm Accountancy Data Network.

EP 2014 (61) 1 (87-102) 
half of the total area of the country for economic purposes, it sets the main functions and directions of land use and shapes the natural environment and landscape. The agricultural sector remains the place of work for almost $15 \%$ of the total number of working people. However, the number of people, working in agriculture points to negative relations between the labour resources and land and capital resources thereby causing low efficiency of labour. On the other hand, from the perspective of Gross Domestic Product (GDP) generation the significance of the agricultural sector in Poland is decreasing. The share of agriculture (including hunting and forestry) in GDP has dropped from ca. 9\% in 1990 to $4 \%$ in 2003 and $3.3 \%$ in 2010 . The share of agriculture in replacement and increasing of the assets remains significantly smaller. Investment inputs for this purpose are shaped below $2 \%$, which inevitably leads to further decrease in the role of agriculture as owner of fixed assets in the national economy.

An analysis of labour resources and fixed assets as well as of the share of agriculture in creation of the global product and gross domestic product prove that the productivity of assets is relatively small and that labour productivity in agriculture stagnates (Figure 1). On a country scale, in some regions it still plays an important role, having a strong impact on the level of development and the standard of living of the inhabitants of the regions. In general, agriculture still keeps the traditional character expressed e.g. in fragmented (as compared to such countries as Germany or France) agrarian structure, multi-directional production activity of farms, extensive production techniques, although very radical changes take place also in this scope. These changes are caused primarily by the market economy system and transformation following from CAP instruments and structural policy.

Figure 1. Agriculture in national economy (share in \%)

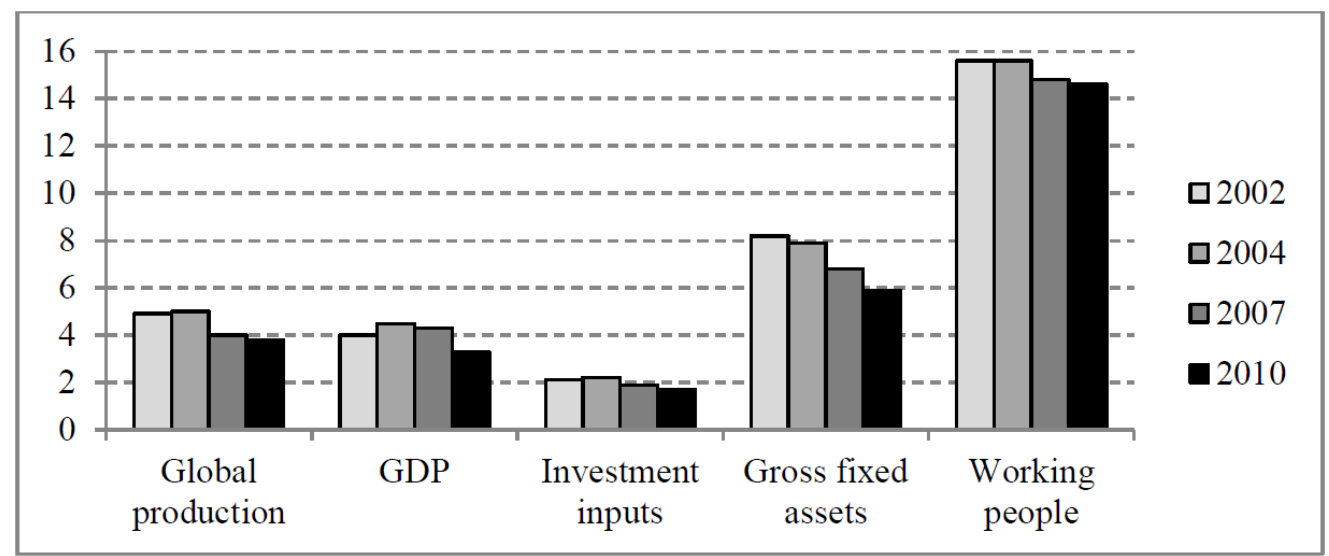

Source: Pracujący w Gospodarce Narodowej (relevant yearbooks), CSO, Warsaw; Środki Trwałe w Gospodarce Narodowej (relevant yearbooks), CSO, Warsaw; Statistical Yearbook of the Republic of Poland, CSO, Warsaw 2011; own calculations. 


\section{Structural changes in agriculture}

In 2002-2010 the land resources of farms have decreased significantly. The total area of land has dropped by ca. $5.5 \%$ from 19,325 thousand ha to 18,257 ha, i.e. by over 1 million ha of agricultural land. The decrease has covered only agricultural land and its area has decreased by 1,365 thousand ha (i.e. by $8.1 \%$ ) from 16,899 thousand ha in 2002 to 15,534 thousand ha in 2010 and this was caused, mainly, by an increase of use outside of agriculture sector abandoned land and the area of grasslands. At the same time, there was an increase in the area of forests and other lands, and or perhaps above all, an increase in area intended for service activities, construction or infrastructure development. The area of agriculture production has decreased by only 415 thousand ha of agricultural land (the aggregated surface of sown area, orchards, meadows and grasslands has dropped from 14,597 thousand ha to 14,182 thousand ha).

Changes in the area structure of farms have also occurred in the discussed period. The total number of farms has decreased from 2,933 thousand to 2,278 thousand, i.e. by 655 thousand (22\%), and the decrease concerned both agricultural parcels (farms up to 1 ha of agricultural land), as well as farms above 1 ha of agricultural land, and the decrease in agricultural parcels amounted to $27 \%$, and in farms above 1 ha of agricultural land - 20\% (in 2010 the number of farms above 1 ha of agricultural land was 1,563 thousand, which means a drop as compared to 2002 by 393 thousand). The structural changes were significantly differentiated in individual area groups. The share of farms below 1 ha has also decreased, while there was a simultaneous increase in the share of units above 1 ha (from 66.6 to 68.6\%). However, in the second group the changes were multi-directional. The number of farms above 1 ha has decreased by $20 \%$ (by 393 thousand), and the number of farms ranging from 1 ha to 30 ha has dropped by 405 thousand, while the number of farms above 30 ha has increased by 12 thousand. A dynamic decrease in the number of the smallest farms (similarly as in the case of agricultural parcels below $1 \mathrm{ha}$ ) resulted from not covering some part of land of these farms with direct payments (because of failure to act by their owners or difficulties in proving that agricultural activity is pursued on the lands). The group of farms with the area above 30 ha has increased from $2.6 \%$ in 2002 to $4 \%$ in 2010, whereas in farms of $30-50$ ha the increase amounted to $12.5 \%$ and in the group of farms greater than 50 ha of agricultural land - the increase amounted to over $40 \%$. However, in 2010 there were only 63 thousand farms of more than 30 ha of agricultural land. From the perspective of competitive potential the structure of land use is more important than the structure of farms. Changes that took place in this scope are, however, similar in their direction since there was a very significant decrease in agricultural land of the smallest farms (1-2 ha by over 30\%), several percent (13.8-17.4\%) in the group of farms of 2-20 ha and an increase in the utilised land resources in the farms of more than 30 ha of agricultural land (the greatest by almost $40 \%$ in the group of 50-100 ha of agricultural land).

The idea behind economic activity in agriculture, just like in other sectors, is production. Introducing elements of production structure to the analysis of agriculture's productivity results from the fact that the volume of obtained production depends not only on the intensity of involvement of production factors and labour force resources (under the given natural conditions), but also on the area of activity on which these factors were involved (Rudnicki, 
1997). However, it is without doubt that structural changes in production are closely related to changes in area structure. In 2002-2010, the number of farms sowing crops has changed by ca. 28\% (from 2,007 thousand to 1,449 thousand), and the average sown area has increased by $1 / 3$ to 7.2 ha (by 1.8 ha) (Table 2.13). There was also a drop in the number of farms growing vegetables (by over $80 \%$ ), potato (by $75 \%$ ), sugar beet (by $50 \%$ ) and cereals (by $22 \%$ ), while the number of farms growing rapeseed (by 100\%) and maize (by 20\%) increased. Production concentration has been visible both in plant and animal production. The size of an average bovine herd has increased from 5.9 to 11 units (and more than $60 \%$ of the population was gathered in herds of more than 20 units), cows from 3.3 to 5.9 units (herds of 10 and more units gathered $67.6 \%$ of the population), pigs from 24 to 38 units (herds of more than 500 units gathered $33 \%$ of the population). In 2010 herds of more than 20 thousand units gathered over $68.2 \%$ of the population of laying hens and over $90 \%$ of the population of broilers.

The direction of changes in the number and structure of farms should be deemed positive (Sikorska, 2013). Farms bigger in terms of land (which gather an increasing percentage of agricultural land) are more and more important. In 2002 the number of farms of more than 20 ha of agricultural land amounted to 51 thousand $(2.6 \%$ of farms of more than 1 ha of agricultural land) and as of 2010 it increased to 63 thousand, but it still is less than $4 \%$ of farms of more than 1 ha of agricultural land. In 2002 these farms utilised 5,509 thousand ha of agricultural land (33.4\% of agricultural land in farms of more than 1 ha of agricultural land), while in 2010 - 6,039 thousand ha of agricultural land (almost $40 \%$ of land resources in farms of more than 1 ha of agricultural land). However, the pace of changes is clearly unsatisfactory (Figure 2).

Figure 2. Changes in the number of farms and area of agricultural land according to the area group in 2002-2012 (in \%)

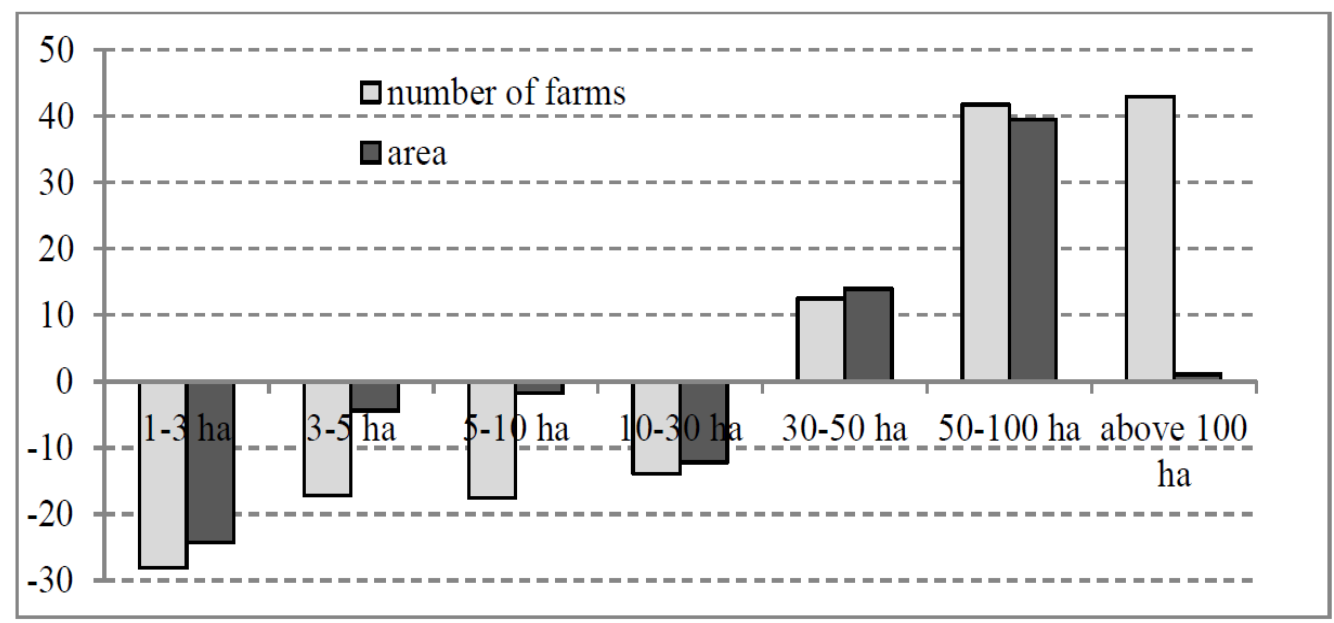

Source: own calculations based on Central Statistical Office data.

The relations showing the provision of the active factor in the production process - i.e. labour, with the two other production factors, namely land and capital give evidence to a 
weak competitive position of the Polish agriculture as regards the competitive potential and preordains law efficiency of labour in sectoral terms and relatively low intensity of agricultural production (relation: capital input - land resources) determines rather law productivity of land (Poczta, 2012).

In 2010 the Polish agriculture had at its disposal ca. 8.5\% of land resources, it involved 18\% of labour input and 5.1\% of capital input in the EU-27 agriculture. Although these relations are not favourable, there was, however, a systematic although relatively small improvement in the relation between land resources (area of agricultural land) and labour input (expressed in $\mathrm{AWU}^{4}$ ), or the sum of indirect consumption and depreciation and labour input (Figure 3). In 2010 the area of agricultural land per 1 AWU in Polish agriculture amounted to only 7.7 ha, which was less than half of the value in the EU-27 (16.4 ha). One unit of labour input has used capital input (sum of intermediate consumption and depreciation) with the value of EUR 7.3 thousand, which amounted to only $30 \%$ of the average level in the EU-27, while intensity of production measured with capital input per 1 ha of agricultural land has amounted to EUR 941, which corresponded to ca. $60 \%$ of the level of these input in EU-27.

Figure 3. Relations between production factors

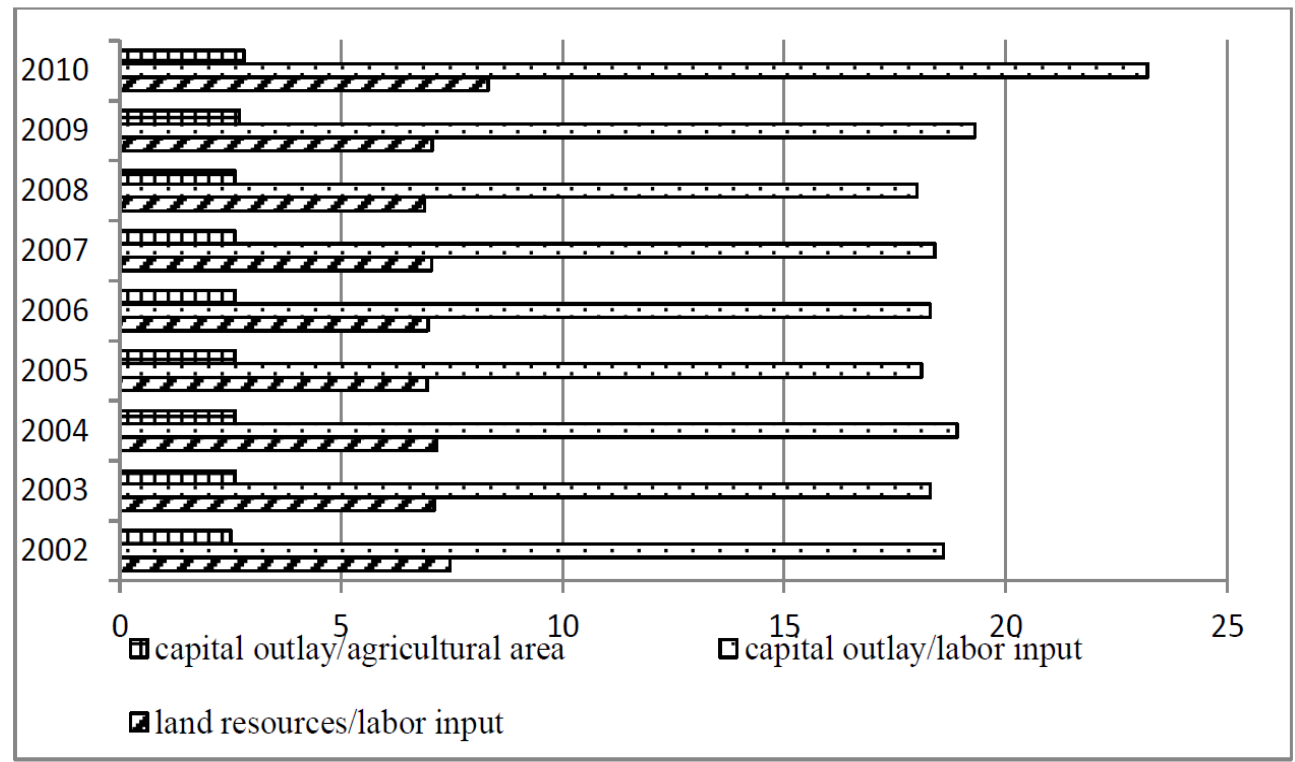

For the relation calculation was adopted: the total area of arable land (thousands of hectares), labour input (thousands $A W U$ ), capital expenditures (intermediate consumption and Depreciation million zt, constant prices of 2005).

Source: Own calculations based on: Rolnictwo w 2007 r., GUS, Warszawa 2008; Rolnictwo w 2008 r., GUS, Warszawa 2009; PSR 2002 - Systematyka i charakterystyka gospodarstw rolnych, GUS, Warszawa 2003; Raport z wyników - Powszechny Spis Rolny 2010, GUS , Warszawa 2011.

4 AWU (Annual Work Unit) - CSO makes it 2,120 work hours per year (265 days x 8 hours) EP 2014 (61) 1 (87-102) 


\section{Economic results of the agricultural sector}

The analyses conducted with the use of Economic Accounts for Agriculture (EAA) ${ }^{5}$ (Floriańczyk, 2013) show that in 2004-2012 (i.e. in the years of Poland's membership in the EU) the value of production in the agricultural sector in current prices, excluding payments to products, has increased from almost PLN 61 billion to over PLN 96 billion. And the increase in nominal value of production was especially strong in 2011 and 2012 (Figure 4). The increase in the value of production was linked primarily to the increase in the prices of agricultural products. For comparison, the value of production in fixed prices (2005) in the examined period has increased from PLN 58.0 billion to PLN 60.5 billion, i.e. within the range of $3 \%$. The highest value of production in fixed prices has been observed in 2009 which was linked to the extremely high crops.

Figure 4. The value of production, gross value added without direct payments and income in agriculture in 2004-2012

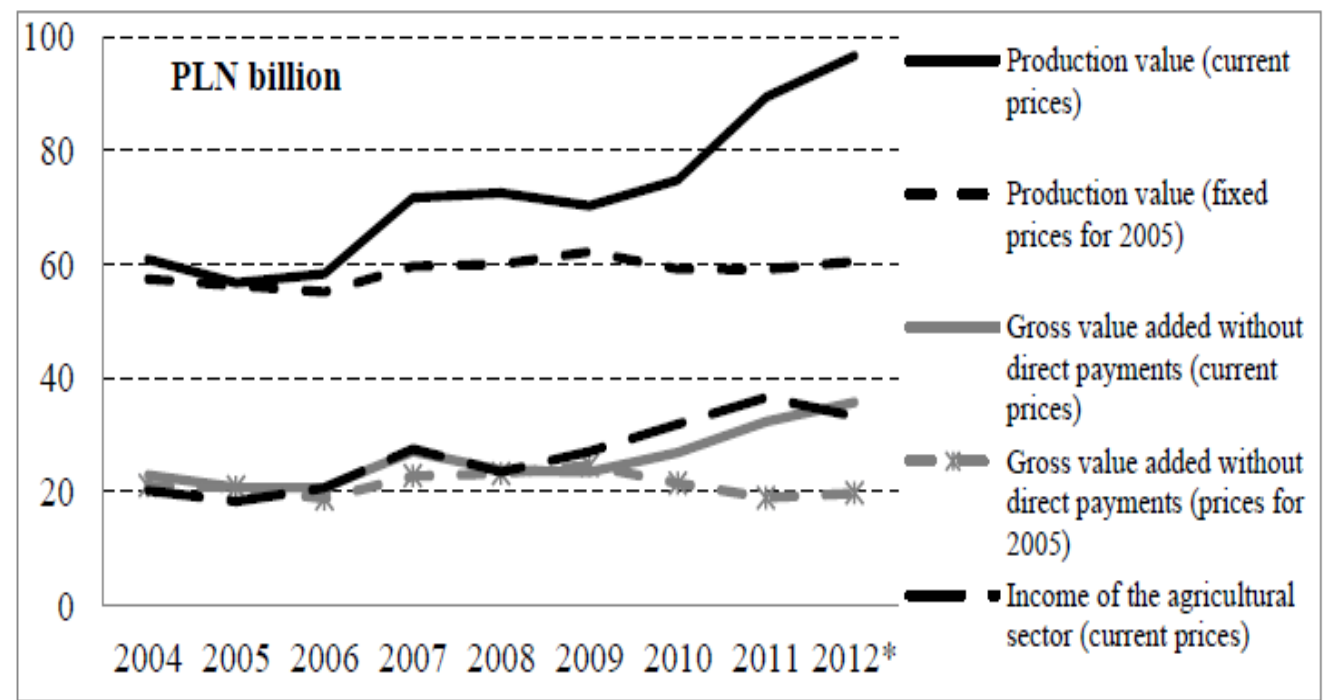

* estimated data

Source: Data for EAA.

Gross value added (GVA) is an important indicator of the effects of agriculture. It is the source of replacement of assets and payment for own work, foreign production factors and taxes, as well as possible resources that may be allocated to different objectives. In 2012 the GVA of the agricultural sector without payments to products reached PLN 35.7 billion and was higher by over $50 \%$ as compared to 2004. It is the highest value of GVA since the time of the accession to the EU. The comparison of GVA in fixed and current prices shows that a high increase in the latter was related to a stronger increase

5 These are satellite accounts as regards some national accounts and they are made by IAFENRI in cooperation with the CSO for the needs of the European Commission. 
in the prices of agricultural products than inputs observed in the last years. Also in real terms, the value of GVA has increased slightly in 2012 although in the previous years it dropped strongly.

As for the value of income from the agricultural sector in 2012 they have reached the level of PLN 33.3 billion (in current prices) and were by almost 15\% lower as compared to 2011. This is an effect of decreasing the total amount of direct support on account of finishing the previous programming period. As a result, in 2012 the total amount of direct support constituted $37 \%$ of agricultural income while in 2011 it was nearly half of that. However, given the record level of income in agricultural sector in 2011 it may be assumed that the high level of income in Polish agriculture after the accession to the EU has been continued.

When examining the EAA it may be seen that in the analysed period the value of plant and animal production has increased, as well as the value of production services provided by agricultural producers for other entities operating in agriculture. This was not caused only by a change in prices, but also different forms of progress, growing level of provision of farms with technical means, reduction of production under unfavourable conditions. Moreover, the rapidly processing denaturalization of consumption affected a drop in the value of home-processed agricultural products despite a price growth (Józwiak, 2012). Starting from 2004 the amounts of payments to production and certain types of products have increased incrementally. Because of the above, the increase in the value of agricultural income, despite an increase in the costs of indirect consumption, was faster and, consequently, the increase in the gross value added was also more rapid.

Differentiation of the structure of farms is often showed as one of the main factors deciding on the economic results of the sector. In order to eliminate the impact of different pace of price change in individual countries on the results of the sector, the economic results of agriculture were analysed in fixed prices of 2000 (Figure 5). In 2000-2010 there was a permanent and significant increase in the value added per 1 employee, but it was small as calculated per 1 ha of agricultural land. The ability to cumulate resources for new investments and perceiving a takeover of farms as an attractive alternative by future successors is significant from the perspective of durability and possibility of further development of farms. Thus it is necessary to assess the production effects in which farms have their share. An increase in the value added from ca. USD 4 to nearly 6 thousand, even under eastern European conditions, does not give evidence to significant economic strength of farms in these countries. 
Figure 5. Value added generated in agriculture per 1 employee, farm and 1 ha in the EU (fixed prices in USD of 2000)

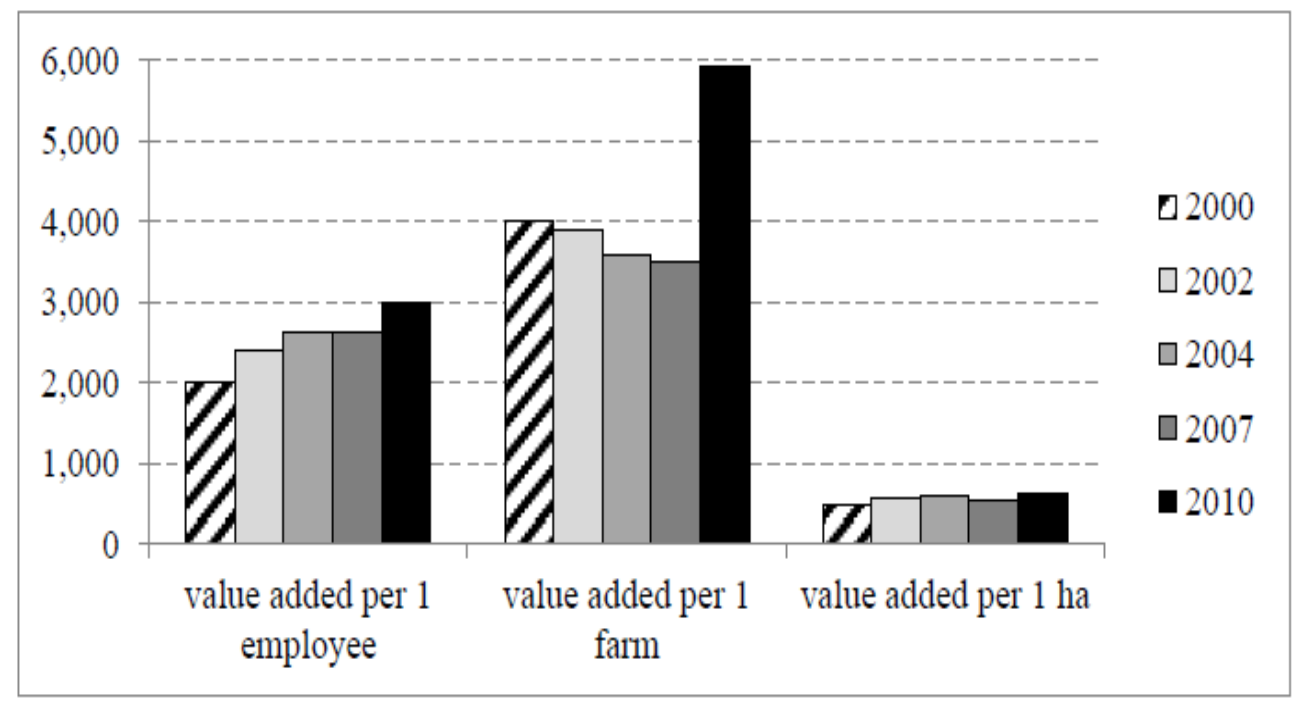

Source: own elaboration based on the data of Eurostat (table ef_lu_ovcropaa) and World Bank (World Development Indicators \& Global Development Finance table EconomicPolicy\&Debt $\backslash$ National Accounts\Agriculture, value added (constant 2000 USD)).

The progress made in the national agriculture was a resultant of activities undertaken by agricultural producers following from growing competition, changes in the prices of agricultural products and means of production, payments to production and products, State aid in the field of investment support and introduced innovations. The last concept encompassed each significant change in the scope of products and production processes, which resulted from solutions created in the country on the basis of licences bought abroad, foreign innovative means of production, results of national research and local invention and technology improvement activities.

\section{The financial dimension of public policies for agriculture and rural areas}

The increase in expenditure on the agricultural sector both in nominal and real terms is the measurable effect of Poland's accession to the EU. This refers to expenditure from the national budget as well as the EU budget (Figure 6). The share of expenditure on agriculture (excluding KRUS) in State budget expenditure has increased over twofold (from almost $2 \%$ in 1997-2004 to ca. 4\% in the 2005-2012 period). An increase in budget expenditure for agriculture and rural areas is a consequence of covering Poland with the CAP and structural policy instruments of the EU, and it follows from the principle of co-financing of the operational programmes and co-financing of the direct payments from the national budget. After 2003 for the first time (since the system transformation) there occurred a chance for direct improvement of the income situation of national agricultural producers and reproduction processes on their farms. The recession break out in Poland took place as a result 
of improvement in the macroeconomic conditions of functioning of the economy, which were seen as an opportunity to stop the growing degradation of the Polish agriculture and rural areas. Increased budgetary inputs were not, of course, able to solve the basic problems of the agricultural sector in Poland straight away, since this requires several years of consistent agricultural policy (Czyżewski, Matuszczak, 2012).

Figure 6. Budgetary expenditure on the agricultural sector in 2004-2012 (PLN million)

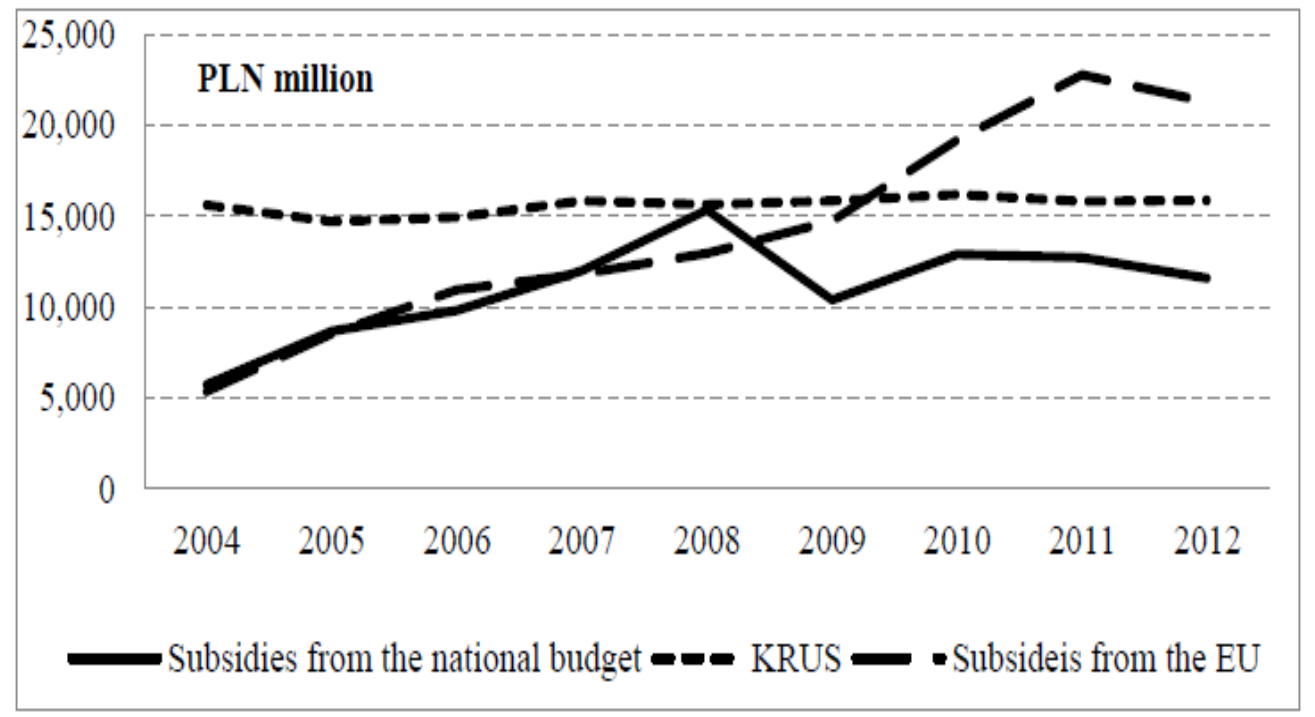

Source: Own elaboration on the basis of Analiza produkcyjno-ekonomicznej sytuacji rolnictwa i gospodarki żywnościowej w 2011, 2009 i 2006 roku, IAFE-NRI, Warsaw (subsequent years) and Czyżewski, A., Opinia o ustawie budżetowej w częściach dotyczących rolnictwa (individual years) Opinie i ekspertyzy, Chancellery of the Senate, the Analyses and Documentation Office.

The budget of the European funds was the main source of financing of the increase in budgetary expenditure on the development of agriculture, food industry and rural areas. In 2012 it amounted to ca. 53\% of the budgetary expenditure on the agricultural sector (including KRUS). These financial resources intended for agriculture development and paid from the EU budget may be divided into four groups according to their impact on growth and structural changes in agriculture:

- entirely direct impact: modernisation of farms, early retirements and diversification of agricultural activity, setting up of young farmers;

- entirely indirect impact: infrastructure, land drainage, land re-parcelling, afforestation, agri-environmental schemes, advisory services;

- partly direct impact: direct payments, support for agricultural activity in lessfavoured areas (LFA), market intervention expenditure, establishment of agricultural producer groups, establishment of micro-enterprises; 
- partly indirect impact: quality of life on rural areas, support to processing industry, PHARE programmes, LEADER programme, village renewal, training, technical assistance.

From the beginning of membership in the EU until June 2013 Poland has received over PLN 180 billion under different support instruments from the EU resources (market intervention, direct support system, rural development programmes, and fisheries policy) and national support (excluding KRUS). The greatest share in these transfers belonged to direct payments (over 50\%) and payments to implementation of rural development programmes (almost 40\%). Poland, like the majority of the new EU Member States, applies the Single Area Payment Scheme (SAPS), under which Single Area Payments (SAP) and Complementary National Direct Payments (CNDP) are provided. Payments are awarded to each hectare of agricultural land in good agricultural condition of a farm whose area exceeds 1 ha. Total area entitled to SAPS in Poland is 14.1 million ha. Each year, applications for single area payments are submitted by ca. 1.35 million farmers and complementary payments - ca. 1.2 million farmers. The Single Area Payments constitutes ca. $60 \%$ of the total amount of payments, while the complementary payments - $30 \%$ of the amount of payments. Other forms of direct payments are insignificant in terms of the total budget of paid direct payments (e.g. animal payments amounted to $5 \%$ of total budget of payments and sugar payments to $4 \%$ ).

The initial level of the Single Area Payment received by Polish farmers was much lower than the average level of payments in the EU-15, since Poland was covered by a 10 -year transition period. The default rate of payment in 2004 amounted to $25 \%$ of the rate in the EU-15, 30\% in 2005, 35\% in 2006, after which it increased by subsequent $10 \%$ each year until reaching $100 \%$ of the average level of payments in the EU-15 in 2013. At the same time, complementary payments were paid from the state budget. They involved all crops excluding fallow land, potatoes other than starch, vegetables and decorative plants (both annual and perennial). In 2004-2010, the amount of cofinancing from the state budget reached $30 \%$, in 2011 it was $20 \%$ and in 2012 it was $10 \%$. In the 2004-2012 period the total amount of support under SAP and CNDP expressed in PLN per 1 ha has increased from ca. PLN 503 to PLN 943 in 2012. The continuous increase in expenditure allocated for direct payments caused an increase in the role of these payments as an income-generating factor in agriculture. Before the accession the subsidies accounted for less than $9 \%$ of the farmers' income, while in the 2009-2012 period (despite the increase in the value of agricultural production in real terms by $20 \%$ ) their share exceeded $60 \%$. 
Figure 7. Aggregated expenditure to CAP implementation in the period from May 2004 to August 2013

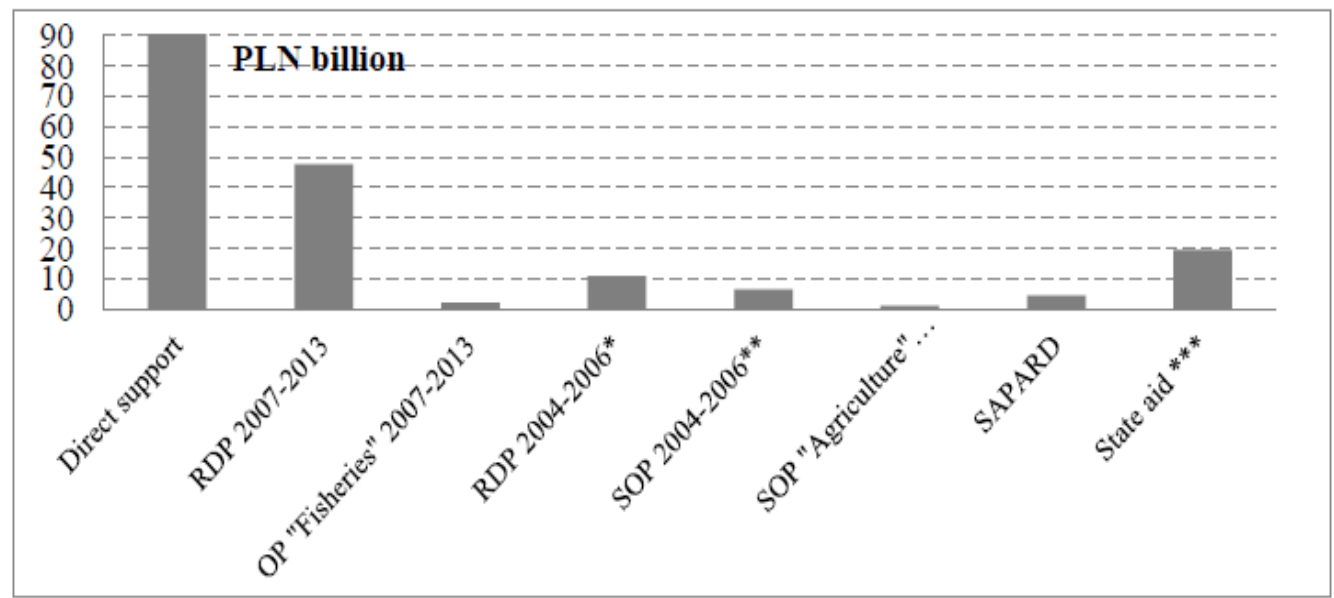

* excluding CNDP 2004-2006; ** along with measures of the Foundation of Assistance Programmes for Agriculture (FAPA) and Offices of the Marshal; *** mainly subsidies to interest rates on loans.

Source: Author's own compilation based on ARMA Management Information System, www.arimr. gov.pl (accessed on: 02.09.2013).

The resources from structural funds of the EU were rather insignificant as it comes to funding changes in the Polish agriculture in 2000-2002. In subsequent years the share of EU budget resources in the funding of changes in the agricultural sector was, however, more significant. The first real programme addressed to villages and rural areas was the pre-accession SAPARD programme with the budget of EUR 946 million. In subsequent years - 2004-2006 (and actually, because of programme settlements, until the end of 2008), two programmes were implemented, e.g.: Rural Development Plan for 2004-2006 (RDP for 2004-2006, with the budget of EUR 3,592 million) and the Sectoral Operational Programme "Restructuring and Modernisation of the Food Sector and Rural Development 2004-2006" (SOP "Agriculture", with the budget of EUR 1,788). The Rural Development Programme (RDP 2007-2013, with the budget of EUR 17,420 million) has been implemented in Poland since 2007. The total amount of public resources - both EU, and national - allocated to rural development under SAPARD, RDP 2004-2006, SOP "Agriculture", and RDP $2007-$ 2013 is EUR 23.7 billion. Financial resources under the programmes implemented in 20002006 (a total of EUR 6.3 billion) were used in full. The RDP 2007-2013 enjoys as much popularity among beneficiaries as its earlier versions (Figure 7). RDP 2007-2013 is the largest assistance programme that invests in rural areas (Wigier, 2012). Among the EU Member States, Poland has at its disposal the largest allocation from EAFRD (EUR 13.4 billion) for the implementation of measures covered by RDP 2007-2013. These funds are supplemented with a State budget contribution, which amounts to EUR 4 billion. In addition, the commitments from 2004-2006, which amount to EUR 3 billion and were undertaken under the Rural Development Plan 2004-2006, are also financed under EAFRD. 


\section{Conclusions}

The share of the contemporary agricultural sector in the generation of the final food product and the generation of the GDP shows a downward trend. Yet, the contribution of nonagricultural elements of food economy increases in that account. The Engel's law, which states that as consumers' income rises, the proportion of income spent on food (in particular the unprocessed one) falls, although nominal value of the expenditure on food rises, has clearly revealed in the Polish food economy, just like in the entire global economy.

Searching for improve the competitiveness and efficiency of the Polish agriculture and increase in the income of the population working in that sector, the improvement of agrarian structure is always mentioned. In the Polish agriculture, just like in the Southern Europe countries and unlike in the Northern and Western Europe countries, there are mostly small farms (up to 10 ha of farmland). Large farms with an area of over 50 ha of agricultural land represent only $1.7 \%$ (of the total of holdings that are involved in agricultural activities), and $30 \%$ of agricultural land is concentrated in them. A weakness of the Polish agriculture consists in the concentration of the most of the production potential (resources) in the agricultural holdings that produce on a small scale. The imperfection of agricultural structures often translates into mistakes in the applied production technologies, and both areas entail low productivity of the factors of production. The micro-economic weakness of most agricultural holdings determines the sectorial weakness of the Polish agriculture on the European Single Market.

When analysing the competitiveness through the prism of stabilisation of agricultural markets and modernisation of the agricultural sector, it should be stated that, after Poland's accession to the EU, significant changes took place that were connected with the previous trend for socialisation of the budget expenditure for growth of expenditure earmarked for financing of structural changes in the agriculture and within rural areas. Among other things due to them, the number of farms in 2002-2012 decreased within area groups in which there are difficulties in achieving a parity income level and development opportunities. An increase in the number of farms took place in area groups in which there was appropriate income guarantees proper performance of the consumption function (parity income level) and the production function (implementation of net investments). The still present imperfection of agricultural structures and the necessity to make adjustments in the relations between the factors of production is a proof that it is necessary to introduce changes consisting in continuing the reduction of labour resources in the agriculture and modernisation of fixed assets.

The CAP instruments covering Poland resulted in doubling the actual income of farmers, which improved their economic situation and increased the opportunities to finance the current expenditure and to implement modernisation investments. However, the agricultural sector needs further transformations in the field of agrarian and production structures, and the EU's CAP should be an important stimulant thereof. After the accession, a considerable production and economic progress was made, but its competitiveness does not represent a strong foundation of international competitiveness. In the Polish exports on the European Single Market there are mostly higher processed products (which results from competitive advantage basing on lower labour costs and processing fees in the Polish food sector) and 
labour-intensive products. Because of cheap labour force, the agricultural sector has an advantage in labour-intensive production areas, which is in accordance with the HeckscherOhlin theorem.

\section{References}

1. Czyżewski, A., Matuszczak, A. (2012): Krajowe $i$ unijne finansowanie wydatków budzetowych $w$ sektorze rolno-żywnościowym $w$ latach 1996-2012, Journal of Agribusiness and Rural Development, Wydawnictwo Uniwersytetu Przyrodniczego w Poznaniu, Vol. 2(24), pp. 5-22.

2. Floriańczyk, Z. (2013): Dochód polskiego sektora rolnego w roku 2012 na tle lat poprzednich, IAFE-NRI, Warsaw, Typescript, pp. 7-9.

3. Goraj, L., Mańko, S. (2011): Model szacowania pełnych kosztów działalności gospodarstw rolnych, Zagadn. Ekon. Roln., no. 4., IERiGŻ-PIB, Warsaw, pp. 28-58.

4. Józwiak, W. (2009): Zdolność konkurencyjna polskich gospodarstw rolnych w zestawieniu z gospodarstwami wegierskimi i niemieckimi. In: Sytuacja ekonomiczna, efektywność funkcjonowania i konkurencyjność polskich gospodarstw rolnych osób fizycznych. Ed. W. Józwiak, IERiGŻ - PIB, Warsaw.

5. Józwiak, W. (2012): Polskie rolnictwo i gospodarstwa rolne w pierwszej i drugiej dekadzie XXI wieku, Multi-annual programme Report No. 53, IAFE-NRI, Warsaw.

6. Meredyk, K. (2001): Przesłanki wzrostu konkurencyjności gospodarki polskiej, [in] Konkurencyjność gospodarki Polski w dobie integracji z UE i globalizacji, J. Bossak, W. Bieńkowski (Ed.), Materiały konferencyjne, SGH, Warsaw.

7. Nicholls, W. H. (1964): The place of agriculture in economic development, In: Agriculture in economic development, Ed. C. Eicher, L. Witt, McGraw-Hill, New York.

8. Poczta, W. (2012): Przemiany w rolnictwie ze szczególnym uwzględnieniem przemian strukturalnych, In: Raport o stanie wsi. Polska wieś 2012, (Ed.) Wilkin J. Nurzyńska I., Wydawnictwo Naukowe SCHOLAR, FDPA, Warsaw, pp. 72-77.

9. Porter, M. E. (1995): Toward a Dynamic of Strategy, In: Fundamental Issues in Strategy, A Research Agenda ed. by R. P. Rumelt, D. E. Schendel and D. J. Teece, Harvard Business Scholl Press, Boston, Massachusetts, p. 543.

10. Rostow, W. W. (1960): The Stages of Economic Growth: A Non-Communist Manifesto, Cambridge University Press, pp. 4-16.

11. Sikorska, A. (2013): Obrót ziemia a przemiany agrarne $w$ indywidualnym rolnictwie, ZER, no. 1/2013, IAFE-NRI, Warsaw, pp. 8-22.

12. Rudnicki, R. (1997): Geograficzno-ekonomiczne czynniki kształtujace produkcję rolnictwa indywidualnego na przykładzie makroregionu dolnej Wisty, UMK TNT, Toruń.

13. Wigier, M. (2012): Efekty realizacji WPR w Polsce - doświadczenia $i$ wyzwania $w$ 
perspektywie do 2020 roku, In: Polityka ekonomiczna (Ed. J. Sokołowski, M. Sosnowski, A. Żabiński), Prace naukowe nr. 246, Uniwersytet Ekonomiczny we Wrocławiu, pp. 504-513.

14. Woś, A. (2003): Konkurencyjność potencjalna polskiego rolnictwa, In: Źródła przewag konkurencyjnych przedsiębiorstw w agrobiznesie. Zbiór referatów V Konferecji Naukowej (Ed. D. Niezgoda), ed. Katedra Ekonomiki i Organizacji Agrobiznesu Akademii Rolniczej w Lublinie.

15. Wysokińska, Z. (2001): Konkurencyjność w międzynarodowym i globalnym handlu technologiami, PWN, Warsaw.

16.Ziętara, W. (2012): Pozycja konkurencyjna polskich gospodarstw rolnych $w$ procesie integracji i globalizacji, Journal of Agribusiness and Rural Development, vol. 2(24), SGGW, Warsaw, pp. 297-308. 